\title{
Production and water use efficiency of peanut under salt stress and soil cover ${ }^{1}$
}

\author{
Produção e uso eficiente da água do amendoinzeiro sob estresse salino e cobertura do solo
}

\author{
Juvenaldo Florentino Canjá ${ }^{2}$, Jonnathan Richeds da Silva Sales ${ }^{2 *}$, Luciana Luzia Pinho ${ }^{2}$, Naara Iorrana Gomes \\ Sousa $^{2}$, Claudivan Feitosa de Lacerda ${ }^{3}$ and Geocleber Gomes de Sousa ${ }^{4}$
}

\begin{abstract}
Proper management of brackish water can increase plant production in the Brazilian semi-arid region. The objective of this study was to evaluate the production performance and water use efficiency of two peanut genotypes irrigated with brackish water during the reproductive stage, in soil with and without soil cover. The study was conducted in a greenhouse. The experimental design used was randomized blocks, with four replicates, in a $2 \times 2 \times 2$ factorial scheme (two electrical conductivities of irrigation water - ECw 0.9 and $5.0 \mathrm{dS} \mathrm{m}^{-1}$, two peanut genotypes - AC 130 and cv. BR1, and the presence or absence of soil cover). At 72 days after sowing, harvest was performed and the following variables were evaluated: number of marketable pods, number of non-marketable pods, pod mass, diameter and length, production and water use efficiency. Salinity impacted production more than the water use efficiency in the two peanut genotypes, with the relative reduction in production being higher in cv. BR-1. Soil cover with dead plant material mitigated the effects of salinity on production and increased water use efficiency, only in genotype AC 130.
\end{abstract}

Key words - Arachis hypogaea L. Salinity. Salt tolerance.

RESUMO - O manejo adequado de águas salobras pode aumentar a produção vegetal no semiárido brasileiro. Diante disso, objetivou-se avaliar a ação mitigadora da cobertura do solo na produção e eficiência no uso da água em genótipos de amendoim sob estresse salino. O estudo foi conduzido em casa-de-vegetação. O delineamento experimental utilizado foi de blocos casualizados, em esquema fatorial $2 \times 2 \times 2$, sendo duas condutividades elétricas da água de irrigação $(0,9$ e 5,0 dS m $\mathrm{d}^{-1}$ ), dois genótipos de amendoim (AC 130 e cv. BR-1) e a presença e ausência da cobertura vegetal morta, com quatro repetições. Aos 72 dias após a semeadura foi realizada a colheita das vagens e avaliadas as seguintes variáveis: vagens comerciais, vagens não comerciais, massa, diâmetro e comprimento da vagem, produção e eficiência no uso da água. A salinidade impactou mais a produção do que a eficiência do uso da água nos dois genótipos de amendoim, sendo que a redução relativa na produção foi maior na cv. BR-1. A cobertura do solo com material vegetal morto minorou os efeitos da salinidade sobre a produção e aumentou a eficiência do uso da água, apenas no genótipo AC 130.

Palavras-chave: Arachis hypogaea L. Salinidade. Tolerância à salinidade.

DOI: $10.5935 / 1806-6690.20210040$

Editor-in-Article: Prof. Alek Sandro Dutra - alekdutra@ufc.br

*Author for correspondence

Received for publication on 14/01/2021; approved on 27/04/2021

${ }^{1}$ Trabalho extraído da dissertação do primeiro autor apresentada no Programa de Pós-Graduação em Engenharia Agrícola da Universidade Federal do Ceará/UFC

${ }^{2}$ Departamento de Engenharia Agrícola, Universidade Federal do Ceará/UFC, Fortaleza-CE, Brasil, batchijuve@gmail.com (ORCID ID 0000-0002-1342-4326), jonnathanagro@gmail.com (ORCID ID 0000-0003-4970-719X), englucianaufc@gmail.com (ORCID ID 0000-0003-3458-713X), naara_ iorrana@hotmail.com (ORCID ID 0000-0002-6599-6588)

${ }^{3}$ Departamento de Engenharia Agrícola, Universidade Federal do Ceará, Fortaleza-CE, Brasil, cfeitosa@ufc.br (ORCID ID 0000-0002-5324-8195)

${ }^{4}$ Instituto de Desenvolvimento Rural, Universidade da Integração Internacional da Lusofonia Afro Brasileira/UNILAB, Redenção-CE, Brasil, sousagg@unilab.edu.br (ORCID ID 0000-0000-0002-1466-6458) 


\section{INTRODUCTION}

Peanut (Arachis hypogaea L.) is an oilseed crop of wide utilization as food, with high importance both in the socioeconomic sphere and in the food field not only in Brazil, but also in the world (SANTOS et al., 2012b; SÁ et al., 2020). According to an estimate by the National Supply Company (CONAB, 2020), the average yield of the peanut crop in Brazil, in 2020, was 3,564 $\mathrm{kg} \mathrm{ha}^{-1}$. However, for its production to become feasible, factors that favor the production potential of the crop are necessary, such as quantitative and qualitative irrigation management.

In the Brazilian semi-arid region, full or supplemental irrigation becomes necessary due to the low rainfall and long periods of drought. However, most of its water sources have a high salt content, which may impact soil and crop yield (HOLANDA et al., 2016).

The salinity of irrigation water is one of the main abiotic constraints in global food production, and its effects are particularly critical in semi-arid and arid regions (MINHAS et al., 2020). The negative effects of salt stress on plants are directly related to osmotic, ionic and nutritional effects, causing imbalance in plant water relations and the accumulation of potentially toxic ions, mainly due to the predominance of $\mathrm{Na}^{+}$and $\mathrm{Cl}^{-}$ions (LACERDA et al., 2011; PRAZERES et al., 2015). The direct and indirect effects of salinity lead to stomatal closure, reduction in transpiration and photosynthesis rates (SÁ et al., 2018), consequently favoring the reduction of crop quality and yield (ZHANG, 2015).

According to Ayers and Westcot (1999), the peanut crop tolerates irrigation with brackish water with electrical conductivity of up to $3.2 \mathrm{dS} \mathrm{m} \mathrm{m}^{-1}$, without reduction in production. This crop, according to Graciano et al. (2011), develops physiological mechanisms capable of ensuring its growth when irrigated with moderately brackish waters. However, studies on the effects of irrigation with brackish water in the reproductive stage are scarce. When analyzing the effects of using brackish water and pulse and continuous drip irrigation on peanut crop, Cruz et al. (2021) observed no negative effects of salinity $\left(2.98 \mathrm{dS} \mathrm{m}^{-1}\right)$ on grain yield and production characteristics.

It is worth pointing out that there is great variability between species and between cultivars of the same species in relation to the tolerance to irrigation with brackish waters, ranging from low to high capacity to tolerate excess salts in the growing medium (SOARES FILHO et al., 2016). This variability allows the identification of genotypes that can grow, develop and produce in these environments, as a purpose of coexistence with the salinity problem in semi-arid environments (SOARES FILHO et al., 2016; FREIRE et al., 2018).
The effects of irrigation water salinity can also be minimized with the use of management strategies, which particularly includes the application of dead vegetation cover to the soil (LACERDA et al., 2021). This technique is presents itself as a conservation practice, which can minimize excessive water losses, prolonging moisture and reducing soil temperature fluctuations (SOUSA et al., 2018; BARBOSA et al., 2021). This may favor the dilution of salts in the root zone (LESSA et al., 2019), which facilitates the absorption of water by the roots under saline conditions.

Thus, it is hypothesized that the use of dead vegetation cover in the soil attenuates salt stress in peanut genotypes in the reproductive stage. Therefore, the objective was to evaluate the mitigating action of soil cover on the production and water use efficiency in peanut genotypes under salt stress.

\section{MATERIAL AND METHODS}

The study was conducted from October to December 2019 in a greenhouse, located in the experimental area of the Agrometeorological Station, at the Department of Agricultural Engineering, Federal University of Ceará (UFC), Fortaleza ( $3^{\circ} 45^{\prime} \mathrm{S} ; 38^{\circ} 33^{\prime}$ $\mathrm{W}$ and altitude of $19 \mathrm{~m}$ ), Ceará, Brazil. The data of air temperature and relative humidity were monitored by a Data Logger (HOBO ${ }^{\circledR}$ U12-012 Temp/RH/Light/Ext), obtaining temperature and relative humidity averages of $27.0^{\circ} \mathrm{C}$ and $78 \%$, respectively.

The experimental design used was randomized blocks, with four replicates, in a $2 \times 2 \times 2$ factorial scheme, corresponding to two electrical conductivities of irrigation water - ECw (0.9 and $\left.5.0 \mathrm{dS} \mathrm{m}^{-1}\right)$, two peanut genotypes (AC 130 and cv. BR-1) and the presence and absence of soil cover, with four replicates and two plants per experimental unit. The substrate used was composed of arisco (sandy material with light texture normally used in constructions in Northeast Brazil), soil and humus in the volume proportion of $7: 2: 1$, whose chemical attributes are described in Table 1.

Water of $0.9 \mathrm{dS} \mathrm{m}^{-1}$ was obtained in a deep well located in the Agrometeorological Station of UFC, which had pH, EC $\left(\mathrm{dS} \mathrm{m}{ }^{-1}\right), \mathrm{Ca}^{2+}, \mathrm{Mg}^{2+}, \mathrm{Na}^{+}, \mathrm{K}^{+}, \mathrm{Cl}^{-}$ and $\mathrm{HCO}_{3}\left(\right.$ mmolc L $\left.\mathrm{L}^{-1}\right)$ of $7.7,0.9,1.2,2.8,4.9,0.4,7.2$ and 2.3 , respectively. High-salinity water $\left(5.0 \mathrm{dS} \mathrm{m}^{-1}\right)$ was prepared from the dissolution of $\mathrm{NaCl}, \mathrm{CaCl}_{2} \cdot \mathrm{H}_{2} \mathrm{O}$ and $\mathrm{MgCl}_{2} \cdot 6 \mathrm{H}_{2} \mathrm{O}$ salts, in equivalent ratio of $7: 2: 1$. The proportion of salts used is a representative approximation of most sources of water available for irrigation in the Northeast region of Brazil (MEDEIROS, 1992). 
Table 1 - Chemical characteristics of the substrate used in the experiment

\begin{tabular}{|c|c|c|c|c|c|c|c|c|c|c|c|}
\hline O.M. & $\mathrm{N}$ & $\mathrm{pH}$ & $\mathrm{P}$ & $\mathrm{K}^{+}$ & $\mathrm{Ca}^{2+}$ & $\mathrm{Na}^{+}$ & $\mathrm{Mg}^{2+}$ & $\mathrm{H}^{+}+\mathrm{Al}^{3+}$ & \multirow{2}{*}{ SB } & ESP $(\%)$ & $\mathrm{EC}(1: 1)$ \\
\hline \multicolumn{2}{|c|}{$\left(\mathrm{g} \mathrm{kg-}^{-1}\right)$} & $\left(\mathrm{H}_{2} \mathrm{O}\right)$ & $\left(\mathrm{mg} \mathrm{kg-}^{1}\right)$ & \multicolumn{5}{|c|}{$\mathrm{cmol}_{\mathrm{c}} \mathrm{dm}^{-3}$} & & & $(\mathrm{dS} \mathrm{m-1})$ \\
\hline 0.92 & 0.05 & 6.4 & 102 & 0.5 & 0.4 & 0.05 & 0.3 & 3.96 & 1.08 & 4 & 0.9 \\
\hline
\end{tabular}

O.M. - organic matter; SB - sum of bases; ESP - exchangeable sodium percentage; EC - electrical conductivity

Table 2. Volume of water consumed (mean \pm standard error) by peanut genotypes in the reproductive stage

\begin{tabular}{lccc}
\hline \multirow{2}{*}{ Genotype } & \multirow{2}{*}{$\mathrm{ECw}\left(\mathrm{dS} \mathrm{m}{ }^{-1}\right)$} & With cover & Without cover \\
\cline { 3 - 4 } AC 130 & 0.9 & $57.27 \pm 3.33$ & $64.30 \pm 2.69$ \\
& 5.0 & $37.63 \pm 2.08$ & $40.63 \pm 2.02$ \\
\hline \multirow{2}{*}{ BR-1 } & 0.9 & $63.15 \pm 5.51$ & $66.59 \pm 5.50$ \\
& 5.0 & $42.52 \pm 1.83$ & $45.83 \pm 3.56$ \\
\hline
\end{tabular}

Seeds of the accession AC 130 were obtained from the germplasm bank of the University for International Integration of the Afro-Brazilian Lusophony (UNILAB). These seeds have black color and rounded shape, and the pod can contain 3 to 4 seeds. The cv. BR-1 was obtained from the same germplasm bank. The seeds are red and rounded, belonging to the Valencia group, and the pod can contain between 3 and 4 seeds.

Plastic pots with capacity of $25 \mathrm{~L}$ ( $35 \mathrm{~cm}$ height and upper and lower diameters of 34 and $23 \mathrm{~cm}$, respectively) were used for sowing, and a 0.5 -L layer of crushed stone No. 0 was placed at the bottom to facilitate drainage. The pots were filled with 23.0 liters of previously prepared substrate up to a height of $2.0 \mathrm{~cm}$ from the upper edge. For soil cover, a 2.0-cm-thick layer consisting of sugarcane straw collected in the municipality of Redenção, Ceará, was deposited.

Sowing was carried out by placing 5 seeds per pot, and irrigation was performed with $0.9 \mathrm{dS} \mathrm{m}^{-1}$ water in all pots, keeping the substrate at field capacity, and thinning was performed at 14 days after sowing (DAS), leaving two plants per pot. The saline treatments began to be differentiated at the beginning of the reproductive stage, at 28 DAS, adopting the drainage lysimeter method in irrigation management, and 8 pots were selected for this purpose (1 lysimeter for each treatment). The irrigation interval was two days, and irrigation was always carried out in the first hours of the day. One day before the beginning of differentiation of the treatments, fertilization with NPK was performed by applying per pot: $2 \mathrm{~g}$ of urea, $1 \mathrm{~g}$ of single superphosphate and $1 \mathrm{~g}$ of potassium chloride.

After each irrigation, the drainage volume was collected from the lysimeters and a leaching fraction of 0.15 was applied as proposed by Ayers and Westcot (1999). Twenty-two irrigation events were performed, and the data relative to water consumption (Table 2) were tabulated in a spreadsheet in order to calculate the water use efficiency (WUE) for the two genotypes as a function of the treatments applied.

At 72 DAS, the pods were harvested and the following variables were evaluated: number of marketable pods (NMP), fully formed; number of nonmarketable pods (NNMP), defined as those that did not contain seeds; pod mass (PM), determined using an analytical scale with results expressed in grams $(\mathrm{g})$; pod diameter (PD) and pod length (PL), using digital caliper with results in millimeters and centimeters, respectively; grain production per pot (PROD); and water use efficiency (WUE), obtained by relating grain production and the volume of water applied in irrigation $\left(\mathrm{g} \mathrm{L}^{-1}\right)$.

The results obtained were subjected to analysis of variance (ANOVA) and, when significant according to the F test, the means were compared by Tukey test at 0.05 and 0.01 probability levels, using the computer program Assistat 7.7 (SILVA; AZEVEDO, 2016).

\section{RESULTS AND DISCUSSION}

It was verified from the analysis of variance (Table 3) that there was triple interaction $(p<0.01$ or $p<0.05)$ between the factors studied for the following variables: number of marketable pods (NMP), average dry mass of the pod (PM), production (PROD) and water use efficiency (WUE). For the variables number of non-marketable 
pods (NNMP) and pod diameter (PD), an individual effect of salinity was observed $(p<0.01$ or $p<0.05)$. For pod length $(P L)$, a significant interaction $(p<0.05)$ was observed between salinity and soil cover.

The ability to form viable pods, that is, reproductive efficiency in peanut crop, can be affected by several factors, such as: growth habit (prostrate or erect), flower bud height on the main stem and secondary branches, flower viability, partitioning of metabolic energy to the detriment of vegetative growth and crop management (SANTOS, 2000). This occurrence was observed in the performance of the studied genotypes; in absolute terms, CA 130 was superior in terms of the production of pods (Table 3). On the other hand, the cv. BR-1 showed a lower number of non-marketable pods, which may be related to the improvement made in this cultivar for the tropical semi-arid region. However, the difference in percentage terms was small, with 17 and $21 \%$ of non-marketable pods in the genotypes BR-1 and AC 130, respectively.

The increase in salinity caused a slight increase in pod diameter (PD), with a $4.64 \%$ higher mean under high salinity compared to the treatment with low-salinity water (Table 3). It is observed that the reduction in physiological activities due to the osmotic and toxic effects associated with excess of salts in the root zone can also alter the translocation and partition of assimilates. In this case, there may have been a greater partition to protect the fruit, increasing the thickness of its peel to the detriment of the length, which would explain the increase in pod diameter in the treatment of higher salinity.

Table 4 shows the analysis of the interaction between the studied factors for the production variables of peanuts. The increase in irrigation water salinity did not reduce the NMP of the genotype AC 130 when soil cover was used,

Table 3 - Summary of the analysis of variance and means for the variables number of marketable pods (NMP), number of nonmarketable pods (NNMP), pod length (PL), pod diameter (PD), pod mass (PM), production (PROD) and water use efficiency (WUE) in peanut genotypes irrigated with brackish water in the reproductive stage, with and without soil cover

\begin{tabular}{|c|c|c|c|c|c|c|c|c|}
\hline \multirow{2}{*}{ SV } & \multirow{2}{*}{ DF } & \multicolumn{7}{|c|}{ Mean square } \\
\hline & & NMP & NNMP & PL & PD & $\mathrm{PM}$ & PROD & WUE \\
\hline SAL (S) & 1 & $666.12 *$ & $94.53 * *$ & $0.12^{\mathrm{ns}}$ & $2.89 *$ & $414.86^{* *}$ & $29140.78 * *$ & $1.81 * *$ \\
\hline (GEN) & 1 & $6.12^{\mathrm{ns}}$ & $9.03^{\mathrm{ns}}$ & $0.00^{\mathrm{ns}}$ & $0.21^{\mathrm{ns}}$ & $22.54^{\mathrm{ns}}$ & $1072.48^{\mathrm{ns}}$ & $0.32^{\mathrm{ns}}$ \\
\hline $\operatorname{COV}(\mathrm{C})$ & 1 & $98.00^{\mathrm{ns}}$ & $0.28^{\mathrm{ns}}$ & $2.44 * *$ & $1.21^{\mathrm{ns}}$ & $1.76^{\mathrm{ns}}$ & $1687.77^{*}$ & $4.53 * *$ \\
\hline SxGEN & 1 & $180.50^{\mathrm{ns}}$ & $8.11^{\mathrm{ns}}$ & $0.04^{\mathrm{ns}}$ & $1.11^{\mathrm{ns}}$ & $42.38 *$ & $132.48^{\mathrm{ns}}$ & $2.50 * *$ \\
\hline $\mathrm{S} \times \mathrm{C}$ & 1 & $171.12^{\mathrm{ns}}$ & $0.78^{\mathrm{ns}}$ & $1.15^{*}$ & $0.24^{\mathrm{ns}}$ & $54.57 *$ & $3459.12 * *$ & $3.10 * *$ \\
\hline GEN x C & 1 & $105.12^{\mathrm{ns}}$ & $0.67^{\mathrm{ns}}$ & $0.02^{\mathrm{ns}}$ & $0.49^{\mathrm{ns}}$ & $21.99^{\mathrm{ns}}$ & $70.50^{\mathrm{ns}}$ & $0.06^{\mathrm{ns}}$ \\
\hline S x GEN x C & 1 & $2812.50 * *$ & $7.41^{\mathrm{ns}}$ & $0.01^{\mathrm{ns}}$ & $0.06^{\mathrm{ns}}$ & $61.21 *$ & $3753.71 * *$ & $1.43 * *$ \\
\hline Treatments & 7 & $577.07 * *$ & $17.21^{\mathrm{ns}}$ & $0.06^{\mathrm{ns}}$ & $0.68^{\mathrm{ns}}$ & $88.47 * *$ & $5786.40 * *$ & $1.96^{* *}$ \\
\hline Blocks & 3 & $115.75^{\mathrm{ns}}$ & $3.03^{\mathrm{ns}}$ & $0.18^{\mathrm{ns}}$ & $1.60^{*}$ & $13.35^{\mathrm{ns}}$ & $710.01^{\mathrm{ns}}$ & $0.33^{\mathrm{ns}}$ \\
\hline Residual & 21 & 95.94 & 4.36 & 0.15 & 0.42 & 9.31 & 342.63 & 0.14 \\
\hline Total & 31 & & & & & & & \\
\hline \multirow[t]{2}{*}{ CV (\%) } & & 19.54 & 16.03 & 13.43 & 5.16 & 11.52 & 9.72 & 9.92 \\
\hline & & - & - & $\mathrm{cm}$ & $\mathrm{mm}$ & $\mathrm{g}$ & $\mathrm{g}$ & $\mathrm{g} \mathrm{L}^{-1}$ \\
\hline $0.9 \mathrm{dS} \mathrm{m}^{-1}$ & & $56.06 \mathrm{a}$ & $11.50 \mathrm{a}$ & $3.02 \mathrm{a}$ & $12.31 \mathrm{~b}$ & $30.10 \mathrm{a}$ & $220.58 \mathrm{a}$ & $3.58 \mathrm{~b}$ \\
\hline $5.0 \mathrm{dS} \mathrm{m}^{-1}$ & & $46.43 \mathrm{~b}$ & $12.62 \mathrm{a}$ & $2.89 \mathrm{a}$ & $12.91 \mathrm{a}$ & $22.90 \mathrm{~b}$ & $160.23 \mathrm{~b}$ & $4.06 \mathrm{a}$ \\
\hline AC 130 & & $54.56 \mathrm{a}$ & $14.18 \mathrm{a}$ & $2.96 \mathrm{a}$ & $12.69 \mathrm{a}$ & $27.34 \mathrm{a}$ & $196.20 \mathrm{a}$ & $3.92 \mathrm{a}$ \\
\hline BR-1 & & $47.93 \mathrm{~b}$ & $9.93 \mathrm{~b}$ & $2.95 \mathrm{a}$ & $12.52 \mathrm{a}$ & $25.66 \mathrm{a}$ & $184.62 \mathrm{~b}$ & $3.72 \mathrm{a}$ \\
\hline With cover & & $50.00 \mathrm{a}$ & $10.93 \mathrm{a}$ & $3.23 \mathrm{a}$ & $12.61 \mathrm{a}$ & $26.73 \mathrm{a}$ & $197.67 \mathrm{a}$ & $4.19 \mathrm{a}$ \\
\hline Without cover & & $52.50 \mathrm{a}$ & $13.18 \mathrm{a}$ & $2.68 \mathrm{~b}$ & $12.61 \mathrm{a}$ & $26.26 \mathrm{a}$ & $183.15 \mathrm{~b}$ & $3.44 \mathrm{~b}$ \\
\hline
\end{tabular}

SV - Source of variation; DF - Degree of freedom; Salinity (S); Genotypes (GEN); Dead vegetation cover (C); CV - Coefficient of variation; ns - not significant; ** and * - significant at 0.01 and 0.05 probability levels by $\mathrm{F}$ test, respectively. Means followed by the same letter in the column do not differ statistically by Tukey's test $(\mathrm{p}<0.05)$ 
but caused a reduction of $31.64 \%$ when the soil remained without vegetation cover (Table 4). A similar trend was observed for the cv. BR-1, that is, in the absence of soil cover, there was a reduction of $13.27 \%$. The reduction of marketable pods observed in the two genotypes at the highest salinity $\left(5.0 \mathrm{dS} \mathrm{m}^{-1}\right)$ when the soil remained uncovered can be explained by the imposed conditions, which affects the net $\mathrm{CO}_{2}$ assimilation, causing early senescence of mature leaves and, as a consequence, reduction of leaf area to perform photosynthesis and total production of photoassimilates (LACERDA et al., 2003; MUNNS, 2002).

The use of dead vegetation cover under water/salt stress conditions presents itself as an alternative to soften temperature fluctuation, maintaining soil moisture and consequently promoting the dilution of salts in the soil solution (BARBOSA et al., 2021; CARVALHO; RIBEIRO; GOMES et al., 2018), reducing the osmotic and toxic effects associated with excess of salts in the root zone on the physiological and biochemical functions of plants (LACERDA et al., 2011; SOUSA et al., 2020). On the other hand, the absence of vegetation cover intensifies the salinity-inhibiting effect on the reproductive efficiency of peanut plants.

Pod length was influenced by the interaction between salinity levels and soil cover (Table 5). According to the means, the application of the cover did not cause significant differences when plants were irrigated with the two salinity concentrations in the irrigation water. In the treatment without vegetation cover, the increase in salt concentration caused a reduction of $17.06 \%$ in the average pod length. When comparing the treatment of soil cover, a significant effect is observed only in the treatment of higher salinity, with a $27.67 \%$ lower mean in the soil without dead vegetation cover.

The data in Table 5 reinforce the importance of using soil cover as a strategy to mitigate the harmful effects of salts in the root zone. Possibly, the adoption of this practice favored the flow of water in the soil-plant system and the maintenance of leaf turgor, with positive effects on cell expansion and increase in pod length. On the other hand, plants that did not receive this treatment had greater restrictions on the absorption of water and nutrients, resulting in inhibition of leaf growth, as a mechanism to mitigate water losses by transpiration (TAIZ et al., 2017), consequently limiting the production and partition of photoassimilates (MUNNS, 2002).

The analysis of the interaction of the three factors studied for the variable pod mass (PM) is presented in Table 6. The highest level of irrigation water salinity reduced the PM of the genotype AC 130 by 19.46 and $31.08 \%$, respectively, for treatments with and without soil cover. For the cv. BR-1, these reductions were equal to 30.6 and $31.94 \%$, respectively, values higher than those observed in the

Table 4 - Mean values of the number of marketable pods (NMP) in different genotypes of the peanut crop irrigated with brackish waters under soil cover

\begin{tabular}{lccc}
\hline \multirow{2}{*}{ Genotypes } & ECw $\left(\mathrm{dS} \mathrm{m}{ }^{-1}\right)$ & With cover & Without cover \\
\cline { 3 - 4 } AC 130 & 0.9 & $55.25 \mathrm{aB}$ & $66.2 \mathrm{aA}$ \\
& 5.0 & $51.50 \mathrm{aA}$ & $45.25 \mathrm{bA}$ \\
\hline \multirow{2}{*}{ BR-1 } & & & $52.75 \mathrm{aA}$ \\
\hline
\end{tabular}

Means followed by the same lowercase letter in the column and uppercase letter in the row, for each genotype, do not differ statistically from each other by Tukey test at 0.05 significance level

Table 5. Mean values of pod length (PL) in different genotypes of peanut crop, irrigated with brackish water under soil cover

\begin{tabular}{lcc}
\hline \multirow{2}{*}{$\mathrm{ECw}\left(\mathrm{dS} \mathrm{m}{ }^{-1}\right)$} & \multicolumn{2}{c}{ PL $(\mathrm{cm})$} \\
\cline { 2 - 3 } & With cover & Without cover \\
\hline 0.9 & $3.11 \mathrm{aA}$ & $2.93 \mathrm{aA}$ \\
5.0 & $3.36 \mathrm{aA}$ & $2.43 \mathrm{bB}$ \\
\hline
\end{tabular}

Means followed by the same lowercase letter in the column and uppercase letter in the row, for each genotype, do not differ statistically from each other by Tukey test at 0.05 significance level 
genotype AC 130, only in the treatment without soil cover. When comparing the treatments with and without cover, it was verified that for both genotypes the mean values were higher in the treatment that received vegetation cover, but only in the treatment of higher salinity.

Although salinity interfered in the filling of the pods in both genotypes, as shown in Table 6 , it was verified that the strategy of using dead vegetation cover minimized the deleterious effects of salinity in the root zone of the genotype AC 130. This may have minimized the impacts of salt stress during the pod filling stage, favoring the translocation of assimilates to the sink organs (BARBOSA et al., 2021).

On the other hand, the lower means found in the treatment of higher salinity, in the absence of soil cover, can be attributed to the osmotic effects because, in order to reduce energy expenditure, plants are forced to reduce the processes of transpiration and net $\mathrm{CO}_{2}$ assimilation (LACERDA et al., 2003; MUNNS, 2002). In a study with the cultivar BR-1 under salt stress with ECw of 0.1 and $3.5 \mathrm{dS} \mathrm{m}^{-1}$, Santos et al. (2012a) observed that pod mass was reduced with the increase in $\mathrm{ECW}$, due to the reduction of the osmotic potential in the soil solution and the inability of stressed plants to translocate the assimilates to sink organs.
The high level of irrigation water salinity did not reduce the grain yield of AC 130 when soil cover was applied; in the absence of dead vegetation cover, there was a $38.71 \%$ reduction in production (Table 7 ). On the other hand, the cv. BR-1 had its means reduced when brackish water was used in irrigation during the reproductive stage, with similar reductions for treatments with presence (32.5\%) and absence (33.6\%) of the soil cover. For both genotypes, there was no difference between soil cover treatments when water with ECw of $0.9 \mathrm{dS} \mathrm{m}^{-1}$ was used. For the treatment of higher salinity, reductions of 29.6 and $7.0 \%$ were recorded for the genotypes AC 130 and BR-1.

Salinity reduced production in both genotypes, except in AC 130 in the soil cover treatment (Table 7). These negative impacts of salt stress are probably attributed to osmotic, ionic and nutritional effects, which cause imbalance in water and nutritional relationships, especially due to the presence of $\mathrm{Na}^{+}$and $\mathrm{Cl}^{-}$ions, considered potentially toxic (LACERDA et al., 2011; PRAZERES et al., 2015). Positive influences of soil cover were observed on the production, probably due to soil temperature stability and reduction of the rate of water evaporation, maintaining moisture in the soil, promoting the dilution of salts and favoring the absorption of water and nutrients by the roots (CARVALHO; RIBEIRO; GOMES et al., 2018; LESSA et al., 2020).

Table 6 - Mean values of pod mass (PM) in different genotypes of peanut crop, irrigated with brackish water under soil cover

\begin{tabular}{lccc}
\hline \multirow{2}{*}{ Genotypes } & ECw $\left(\mathrm{dS} \mathrm{m}{ }^{-1}\right)$ & Pith cover & Without cover \\
\cline { 3 - 4 } AC 130 & 0.9 & $33.50 \mathrm{aA}$ & $33.07 \mathrm{aA}$ \\
& 5.0 & $26.98 \mathrm{bA}$ & $22.79 \mathrm{bB}$ \\
\hline \multirow{2}{*}{ BR-1 } & & & $29.27 \mathrm{aA}$ \\
\hline
\end{tabular}

Means followed by the same lowercase letter in the column and uppercase letter in the row, for each genotype, do not differ statistically from each other by Tukey test at 0.05 significance level

Table 7 - Mean values of production (PROD) in different peanut genotypes, irrigated with brackish water under soil cover

\begin{tabular}{lccc}
\hline \multirow{2}{*}{ Genotypes } & ECw $\left(\mathrm{dS} \mathrm{m}{ }^{-1}\right)$ & With cover & PROD (g/pot) \\
\cline { 3 - 4 } AC 130 & 0.9 & $207.47 \mathrm{aA}$ & $232.46 \mathrm{aA}$ \\
& 5.0 & $202.42 \mathrm{aA}$ & $142.47 \mathrm{bB}$ \\
\hline \multirow{2}{*}{ BR-1 } & & & $215.01 \mathrm{aA}$ \\
\hline
\end{tabular}

Means followed by the same lowercase letter in the column and uppercase letter in the row, for each genotype, do not differ statistically from each other by Tukey test at 0.05 significance level 
The ratio of production $(\mathrm{g})$ by the applied water volume (L per pot) per treatment showed the behavior of the genotypes regarding water use efficiency (WUE) (Table 8). A better performance was recorded when irrigation was performed with $\mathrm{ECw}$ of $5.0 \mathrm{dS} \mathrm{m}^{-1}$ under soil cover for the genotype AC 130, being $63.0 \%$ higher than at salinity of $0.9 \mathrm{dS} \mathrm{m}^{-1}$. In soil without dead vegetation cover, no significant differences were observed for any of the genotypes. Regarding salinity levels, it is possible to observe, at the highest salinity, that the use of soil cover exceeded by $35.13 \%$ the treatment without the presence of soil cover for the genotype AC 130. For the cv. BR-1, the increase in salinity did not impact WUE; however, for the $\mathrm{ECW}$ of $5.0 \mathrm{dS} \mathrm{m}^{-1}$, the presence of soil cover led to $26.5 \%$ better results compared to the absence of cover.

It is important to highlight that the genotypes showed differences in water consumption in the reproductive stage (Table 2), which may be related to genetic characteristics and cultivation conditions. In general, the highest values of water consumption were observed in the genotype BR1 and in treatments without soil cover. The treatments with soil cover and irrigated with the highest salinity had lower water consumption, which express the reductions in water evaporation directly from the soil, caused by the presence of dead vegetation cover, and in the transpiration of the plants, associated with the osmotic effect of salinity and with the reduction of leaf area itself. These variations in water consumption (Table 2) and production responses (Table 7) explain the differences in water use efficiency observed between genotypes and treatments.

The fact that the effects of salinity were significant on production and not on water use efficiency indicates that there was an adjustment between the size of leaf area and the transpiration of the whole plant, under stress conditions, and that the presence of vegetation cover contributed to the dilution of salts in the root zone (SOUSA et al., 2018). As a consequence, there may

Table 8 - Mean values of water use efficiency (WUE) in peanut genotypes, irrigated with brackish waters under soil cover

\begin{tabular}{lccc}
\hline \multirow{2}{*}{ Genotypes } & \multirow{2}{*}{ ECw $\left(\mathrm{dS} \mathrm{m}{ }^{-1}\right)$} & \multicolumn{2}{c}{ WUE $\left(\mathrm{g} \mathrm{L}^{-1}\right)$} \\
\cline { 3 - 4 } & & With cover & Without cover \\
\hline \multirow{2}{*}{ AC 130} & 0.9 & $3.30 \mathrm{bA}$ & $3.50 \mathrm{aA}$ \\
& 5.0 & $5.38 \mathrm{aA}$ & $3.49 \mathrm{aB}$ \\
\hline \multirow{2}{*}{ BR-1 } & 0.9 & $3.99 \mathrm{aA}$ & $3.53 \mathrm{aA}$ \\
& 5.0 & $4.11 \mathrm{aA}$ & $3.25 \mathrm{aB}$ \\
\hline
\end{tabular}

Means followed by the same lowercase letter in the column and uppercase letter in the row, for each genotype, do not differ statistically from each other by Tukey test at 0.05 significance level have been a higher flow of water in the soil-plant system compared to the treatment without soil cover. For this treatment, the higher water losses by evaporation may have contributed to the reduction in soil water content, with consequent increase in salt concentration and decrease in the osmotic potential of the soil solution.

Our results show that the strategy of lower water use with relatively high salt contents, together with the applications of dead vegetation cover, promoted positive effects for the genotype AC 130 because, in addition to water saving, there was also higher production of grain mass, especially in the treatment of higher salinity. This strategy possibly allowed the decrease in the concentration of salts near the roots. The evidence presented in the present study indicates possible paths in irrigation management for peanut crop, when there are waters of different qualities. It is suggested the use of soil cover with dead plant material as one of the management strategies to reduce the effects of salinity on peanut crop cultivation.

\section{CONCLUSIONS}

1. Salinity impacted production more than water use efficiency in the two peanut genotypes;

2. Salinity resulted in a higher average relative reduction in the production of the $\mathrm{cv}$. BR-1;

3. Soil cover with dead plant material mitigated the effects of salinity on production and increased water use efficiency only in the genotype AC 130.

\section{ACKNOWLEDGMENTS}

The authors thank the National Council for Scientific and Technological Development (CNPq), the Coordination for the Improvement of Higher Education Personnel (CAPES), the National Institute of Science and Technology in Salinity (INCTSal) and the Ceará State Development Agency (ADECE), for providing financial support and granting the scholarship.

\section{REFERENCES}

AYERS, R. S.; WESTCOT, D. W. A qualidade da água na agricultura. 2. ed. Campina Grande: UFPB. 1999. 218 p.

BARBOSA, I. J. et al. Mulch with sugarcane bagasse and bamboo straw attenuates salt stress in cowpea cultivation. Revista Brasileira de Engenharia Agrícola e Ambiental, v. 25, n. 7, p. 485-491, 2021. 
CARVAlHO, D. F.; RIBEIRO, E. C.; GOMES, D. P. Marketable yield of onion under different irrigation depths, with and without mulch. Revista Brasileira de Engenharia Agrícola e Ambiental, v. 22, n. 2, p. 107-112, 2018.

CRUZ, R. I. F. et al. Productivity of irrigated peanut plants under pulse and continuous dripping irrigation with brackish water. Revista Caatinga, v. 34, n. 1, p. 208-218, 2021.

CONAB. COMPANHIA NACIONAL DE ABASTECIMENTO. Acompanhamento de safra brasileiro - grãos: Nono levantamento, junho 2020. Available at: $<$ https://www.conab.gov.br/info-agro/ safras/graos $>$. Access on Dec. 14, 2020.

FREIRE, M. H. C. et al. Emergence and biomass accumulation in seedlings of rice cultivars irrigated with saline water. Revista Brasileira de Engenharia Agrícola e Ambiental, v. 22, n. 7, p. 471-475, 2018.

HOLANDA, J. S. et al. Qualidade da água para irrigação. In: GHEYI, H. R. et al. (ed.). Manejo da salinidade na agricultura: estudos básicos e aplicados. 2.ed. Fortaleza: INCTSal, 2016, cap. 4, p. 35-50.

LACERDA, C. F. et al. Solute accumulation and distribution during shoot and leaf development in two sorghum genotypes under salt stress. Environmental and Experimental Botany, v. 49, n. 2, p. 107-120, 2003.

LACERDA, C. F. et al. Soil salinization and maize and cowpea yield in the crop rotation system using saline waters. Engenharia Agrícola, v. 31, n. 4, p. 663-675, 2011.

LACERDA, C. F. et al. Strategies for the use of brackish water for crop production in Northeastern Brazil. In: TALEISNIK, E.; LAVADO, R. S. (ed.). Saline and alkaline soils in Latin America: natural resources, management and productive alternatives. 1.ed. Chem: Springer, 2021, p. 71-99.

LESSA, C. I. N. et al. Estresse salino, cobertura morta e turno de rega na cultura do sorgo. Revista Brasileira de Agricultura Irrigada, v. 13, n. 5, p. 3637-3645, 2019.

MINHAS, P. S. et al. Coping with salinity in irrigated agriculture: Crop evapotranspiration and water management issues. Agricultural Water Management, v. 227, p. 1-22, 2020.

MUNNS, R. Comparative physiology of salt and water stress. Plant and Cell Environment, v. 25, n. 2, p. 239-50, 2002.
PRAZERES, S. S. et al. Crescimento e trocas gasosas de plantas de feijão-caupi sob irrigação salina e doses de potássio. Agro@ mbiente, v. 9, n. 2, p. 111-118, 2015.

SÁ, F. V. S. et al. Growth, gas exchange and photochemical efficiency of the cowpea bean under salt stress and phosphorus fertilization. Comunicata Scientiae, v. 9, n. 4, p. 668-679, 2018.

SÁ, F. V. S. et al. Tolerance of peanut (Arachis hypogea) genotypes to salt stress in the initial phase. Revista Brasileira de Engenharia Agrícola e Ambiental, v. 24, n. 1, p. 37-43, 2020.

SANTOS, D. B. et al. Produção e parâmetros físiológicos do amendoim em função do estresse salino. Idesia, v. 30, n. 2, p. 69-74, 2012a.

SANTOS, R. C. BRS 151 17: Nova cultivar de amendoim para o Nordeste brasileiro. Pesquisa Agropecuária Brasileira, v. 35, n. 3, p. 665-670, 2000.

SANTOS, R. C. et al. Produtividade de grãos e óleo de genótipos de amendoim para o mercado oleoquímico. Revista Ciência Agronômica, v. 43, n. 1, p. 72-77, 2012 b.

SILVA, F. A. S.; AZEVEDO, C. A. V. de. The Assistat Software Version 7.7 and its use in the analysis of experimental data. African Journal of Agricultural Research, v. 11, n. 39, p. 3733-3740, 2016.

SOARES FILHO, W. S. et al. Melhoramento genético vegetal e seleção de cultivares tolerantes à salinidade. In: GHEYI, H. R.; DIAS, N. S.; LACERDA, C. F.; GOMES FILHO, E. Manejo da salinidade na agricultura: estudos básicos e aplicados (2ed). Fortaleza: Instituto Nacional de Ciência e Tecnologia em Salinidade, p. 259-274, 2016.

SOUSA, G. G. et al. Estresse salino e cobertura morta vegetal na cultura do milho. Revista Brasileira de Agricultura Irrigada. v. 12, n. 7, p. 3078-3089, 2018.

SOUSA, G. G. et al. Morphophysiological characteristics of okra plants submitted to saline stress in soil with organic fertilizer. Comunicata Scientiae, v. 11, p. 1-8, 2020.

TAIZ, L. et al. Fisiologia e desenvolvimento vegetal. 6.ed. Porto Algre: Artmed Editora, 2017, 888 p.

ZHANG, B. MicroRNA: a new target for improving plant tolerance to abiotic stress. Journal of Experimental Botany, v. 66, n. 7 , p. 1749-1761. 2015. 